\title{
Influence of management practices and of scavenging seabirds on availability of fisheries discards to benthic scavengers
}

\author{
Robert W. Furness ${ }^{1, *}$, Ann E. Edwards ${ }^{2,3}$, Daniel Oro ${ }^{4}$ \\ ${ }^{1}$ Institute of Biomedical and Life Sciences, Graham Kerr Building, University of Glasgow, Glasgow G12 8QQ, UK \\ ${ }^{2}$ Alaska Fisheries Science Center-NOAA, REFM Division, 7600 Sand Point Way NE, Seattle, Washington 98115, USA \\ ${ }^{3}$ School of Aquatic and Fisheries Sciences, University of Washington, Seattle, Washington 98195, USA \\ ${ }^{4}$ Institut Mediterrani d'Estudis Avançats IMEDEA (CSIC-UIB), 07190 Esporles, Mallorca, Spain
}

\begin{abstract}
There is great variation in discarding practice among fisheries in different parts of the world. Management systems result in some fisheries discarding mostly fish offal, much of which is macerated into small chunks, while other fisheries discard large (ca. $25 \mathrm{~cm}$ ) whole fish. Scavenging seabirds consume high proportions of most categories of discarded fish and offal (typically 60 to $80 \%$ of discarded roundfish, 70 to $95 \%$ of discarded offal), but tend to avoid discarded benthic invertebrates and fish that are difficult to swallow, such as species with long spines or large flatfish. Amounts and composition of fishery discards and offal reaching benthic scavenging communities are clearly very strongly influenced by the intense but selective consumption by seabirds, and this alteration will depend strongly on details of the fishery management regulations and customs, such as whether or not waste is macerated. There is scope to adjust fisheries management practices to reduce the impact of offal and discards on scavenger communities.
\end{abstract}

KEY WORDS: Fisheries · Discards · Offal · Seabirds · Scavenger · North Sea $\cdot$ Mediterranean Bering Sea

Resale or republication not permitted without written consent of the publisher

\section{INTRODUCTION}

It has been estimated that about 25 to 30 million tonnes (Mt) of fish were discarded by fisheries worldwide each year in the 1980s and early 1990s (Alverson et al. 1994), although some efforts have been made to reduce this amount in recent years (Hall \& Mainprize 2005, Broadhurst et al. 2006). Since these discarded fish are predominantly dead or moribund, fishery discards, along with offal and lost bait, provide a large food supply to marine scavengers. This anthropogenic food supply may be much greater than the amounts of dead organisms naturally available in many marine ecosystems. Consumption of fishery waste by scavenging seabirds has been studied in a wide variety of areas where fishing practices differ considerably, such as the North Sea (Hudson \& Furness 1988, Garthe et al. 1996, Catchpole et al. 2006), the Falklands (Thompson \&
Riddy 1995), South America (Bertellotti \& Yorio 2000, González-Zevallos \& Yorio 2006), the Mediterranean Sea (Oro \& Ruiz 1997, Arcos \& Oro 2002, MartínezAbraín et al. 2002), the Baltic Sea (Garthe \& Scherp 2003) and Australia (Svane 2005). In the present paper, we develop the ideas that taxon-selective and sizeselective consumption of fishery discards and offal by scavenging seabirds, and management decisions by fisheries (for example, legal requirements to discard [or not to discard] at sea, setting of quotas, gear design and compliance, maceration of discards, mincing and submerging of offal, retention of waste for fishmeal and oil production, at-sea versus shoreside production) determine the amounts and composition of fishery waste sinking to the seabed. This may vary seasonally and geographically, as well as in relation to the abundance of alternate foods of scavenging seabirds (Garthe et al. 1996, Louzao et al. 2006). Thus, it seems likely 
that seabirds can alter amounts of fishery waste reaching benthic scavenging communities, but the extent of this 'filtering' by seabirds has not been assessed in the context of food web structure and energy flows.

Seabirds are estimated to consume around 70 to $110 \mathrm{Mt}$ of marine foods per year (Brooke 2004, Karpouzi et al. 2007). Although most seabirds catch live prey, scavenging is a major feeding method employed by a small proportion of seabird species, especially by most of the albatrosses, some petrels and shearwaters, many gulls and skuas, and is a minor feeding method employed by some pelicans, gannets, boobies, frigatebirds and a few cormorants (Del Hoyo et al. 1992, 1996). Scavenging seabirds tend to be large species with energetically inexpensive locomotion (often using gliding or soaring flight), which can travel over long distances in search of food at sea and can feed on occasionally located large prey items. On a global scale, scavenging by albatrosses may represent the largest quantity of fishery waste taken by seabirds, though most studies of scavenging seabird ecology have focused on gulls and skuas.

Many scavenging seabirds have increased dramatically in numbers, and these increases have often been attributed to the feeding opportunities presented over many decades by fishery waste (Mitchell et al. 2004, Oro et al. 2004). However, fisheries may also kill scavenging seabirds through drowning on longline hooks and collision with fishing gear (González-Zevallos \& Yorio 2006, Sullivan et al. 2006), while reduction in discarding rates by fisheries or certain changes in fishery management or practice can result in prey-switching by scavenging seabirds to kill smaller seabirds and their chicks (Votier et al. 2004). Better understanding of seabird foraging ecology and seabird-fisheries interactions may aid conservation and ecosystem management, including improvement of our understanding of the inputs of food from fisheries to benthic scavenging communities. This paper assesses the extent to which selective scavenging by seabirds may affect the inputs of fishery waste to benthic communities, and how these inputs are likely to vary as a consequence of differences in fishery management regulations and practice. We explore these issues by comparing and contrasting fisheries and associated scavenging seabirds, with a particular focus on 3 specific areas, the North Sea, the eastern Bering Sea and Aleutian Islands (BSAI), and the western Mediterranean Sea.

\section{MATERIALS AND METHODS}

We reviewed the literature on scavenging seabirds to extract information on the proportions of discards eaten by seabirds and how these proportions vary by discard type, size, fishery behaviour and statutory regulations affecting fishing and at-sea fish processing procedures. Combining these data with information on discarding rates in different fisheries, we compare the patterns in different regions and fisheries and outline general features of scavenging by seabirds that are consistent across this variation in fishery practice. We then use these data to assess for the first time the extent to which scavenging seabirds modify the amounts of fisheries waste that sink towards the seabed to provide foraging opportunities for pelagic and benthic scavengers. These calculations focus primarily on North Sea and Mediterranean seabird communities, where the most detailed studies of consumption of fishery waste by scavenging seabirds have been carried out, but, where possible, we have included comparable data from other parts of the world.

We computed a 'seabird scavenging index' as the mean numbers of a particular species following fishing vessels divided by the mean density of that species derived from 'at-sea' surveys. Thus, the 'seabird scavenging index' gives a relative measure of the extent to which particular species are attracted to fishing vessels rather than to natural food at sea. We also computed a 'discard consumption success index' as the number of discards swallowed by a particular seabird species during experimental discarding studies in relation to the numbers of that species following the fishing vessels. That index provides a measure of the relative success of different seabird species in obtaining discards from a particular fishery under prevailing conditions. We also combined data on the mean lengths of discards taken by different seabirds with the mean body masses of those species, to explore the size selection by seabirds as a function of their body sizes.

Calculations of offal and discards for at-sea processors in the BSAI fishery management region were derived from NOAA landings and products data for the Alaskan groundfish fishery.

\section{RESULTS}

\section{The North Sea}

In the North Sea, discards from trawl fisheries (i.e. demersal species of fish) have become a key food for scavenging seabirds (Garthe et al. 1996). Without fisheries, demersal species, such as haddock Melanogrammus aeglefinus and whiting Merlangius merlangus, would not be available for these birds as they live too deep for scavenging seabirds to reach. The gadoid trawl fishery in the northern North Sea discards predominantly whole and rather large haddock and whiting, of around 20 to $30 \mathrm{~cm}$ in length, with rather few 
flatfish and very few benthic invertebrates (Hudson \& Furness 1988, Votier et al. 2004). Discards from the Norway lobster Nephrops norvegicus fishery consist of smaller roundfish, especially juvenile whiting of 10 to $15 \mathrm{~cm}$, larger numbers of small flatfish, and large quantities of benthic invertebrates (Garthe et al. 1996, Catchpole et al. 2006). Discards from the beam trawl fishery in the southern North Sea tend to contain large quantities of flatfish and invertebrates with few roundfish (Garthe et al. 1996). All these fisheries discard whole fish, which are predominantly dead or moribund and which sink slowly and, hence, can remain close to the surface for some time owing to the turbulence caused by fishing vessel propellers. The most extensive study of discard consumption by North Sea seabirds (Garthe et al. 1996) showed higher consumption rates in winter than in summer, and that when discarding is performed continuously as a trickle during catch sorting and processing (as was then the normal procedure of fishermen on the observed vessels), seabirds consume very high proportions of offal (94 to $100 \%$ ) and roundfish discards (70 to $92 \%$ ), but only small proportions of discarded flatfish (10 to $35 \%$ ) or benthic invertebrates (3 to $17 \%$ ) (Table 1). Other studies in the North Sea have provided very similar results to this (Table 2). These data indicate that seabirds greatly modify the amounts of fishery waste sinking down towards the seabed (Fig. 1). In the north-western

Table 1. Percentages and sample sizes of discarded offal, roundfish, flatfish and benthic invertebrates eaten by scavenging seabirds at different times of year in the North Sea (data from Garthe et al. 1996). Invert.: invertebrates

\begin{tabular}{|lrrrrr|}
\hline \multirow{2}{*}{ Season } & \multicolumn{5}{c|}{ Discards eaten } \\
\cline { 2 - 6 } & $\begin{array}{c}\text { Offal } \\
(\%)\end{array}$ & $\begin{array}{c}\text { Roundfish } \\
(\%)\end{array}$ & $\begin{array}{c}\text { Flatfish } \\
(\%)\end{array}$ & $\begin{array}{c}\text { Benthic } \\
\text { invert. (\%) }\end{array}$ & $\begin{array}{r}\text { Sample } \\
\text { size (n) }\end{array}$ \\
\hline Winter & 100 & 92 & 35 & 17 & 6020 \\
Spring & 94 & 76 & 22 & 8 & 10344 \\
Summer & 94 & 70 & 10 & 3 & 8518 \\
Autumn & 97 & 82 & 20 & 3 & 5928 \\
Sample size & 5715 & 21848 & 2345 & 902 & 30810 \\
\hline
\end{tabular}

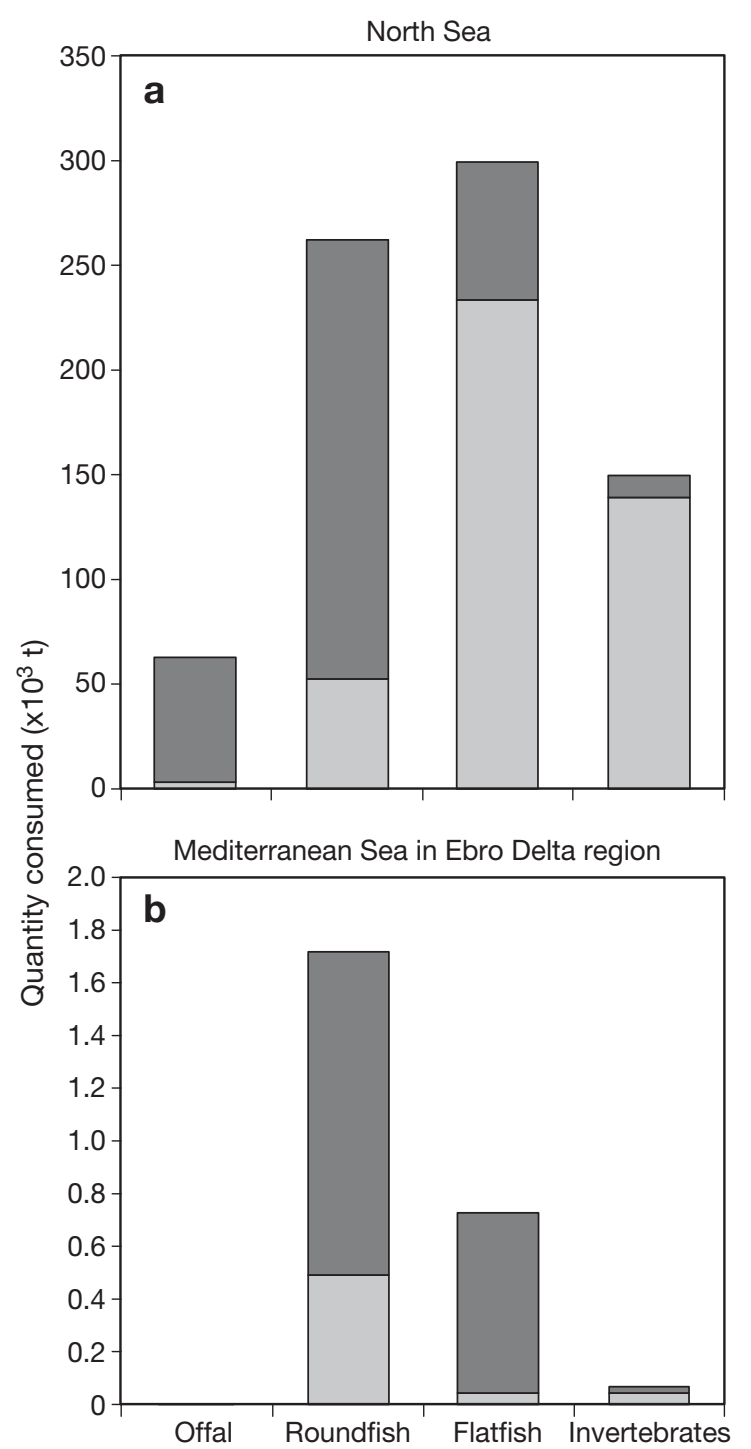

Fig. 1. Quantities (in tonnes) of offal, roundfish, flatfish and benthic invertebrates (estimated to be discarded by fisheries) that were consumed by scavenging seabirds (dark grey bars) or sank without being swallowed by seabirds (light grey bars): (a) North Sea, derived from data in Garthe et al. (1996) and (b) Mediterranean Sea in the Ebro Delta region, derived from data in Oro \& Ruiz (1997) and Arcos (2001)

Table 2. Average consumption rates (\% swallowed) by scavenging seabirds determined by experimental discarding from commercial fishing vessels during routine processing of catches (including discarding by the fishermen) in different regions and fisheries, and related to the typical size (length in $\mathrm{cm}$ ) of fish experimentally discarded in the study fishery

\begin{tabular}{|c|c|c|c|c|c|c|c|}
\hline \multirow[b]{2}{*}{$\begin{array}{l}\text { Northern North Sea } \\
\text { (whitefish trawl) }\end{array}$} & \multirow{2}{*}{$\begin{array}{c}\begin{array}{c}\text { Offal } \\
\text { Rate }(\%)\end{array} \\
99\end{array}$} & \multicolumn{2}{|c|}{$\begin{array}{l}- \text { Roundfish }- \\
\text { Rate }(\%) \text { Length }(\mathrm{cm})\end{array}$} & \multicolumn{2}{|c|}{$\begin{array}{l}\text { Flatfish }- \\
\text { Rate }(\%) \text { Length }(\mathrm{cm})\end{array}$} & \multirow{2}{*}{$\begin{array}{c}\text { Invertebrates } \\
\text { Rate }(\%)\end{array}$} & \multirow{2}{*}{$\begin{array}{c}\text { Source of data } \\
\begin{array}{c}\text { Hudson \& Furness } \\
(1988,1989)\end{array}\end{array}$} \\
\hline & & $>60$ & 28 & $>6$ & 23 & & \\
\hline $\begin{array}{l}\text { Southern North Sea } \\
\text { (whitefish trawl) }\end{array}$ & 96 & 80 & 22 & 22 & 15 & 7 & Garthe et al. (1996) \\
\hline North Sea (Nephrops trawl) & - & 80 & _- & 18 & _- & 16 & Catchpole et al. (2006) \\
\hline Baltic Sea & 87 & 81 & 20 & 8 & 18 & 29 & Garthe \& Scherp (2003) \\
\hline Western Mediterranean Sea & a - & $54-78$ & 10 & $52-70$ & 8 & - & Martínez-Abraín et al. (2002) \\
\hline Patagonia & - & 70 & - & 40 & - & - & Bertellotti \& Yorio (2000) \\
\hline
\end{tabular}


North Sea in summer, northern fulmars Fulmarus glacialis and great black-backed gulls Larus marinus were the most numerous seabirds at trawlers, but the highest scavenging index scores were seen for great black-backed gulls and great skuas Stercorarius skua (Table 3). Fulmars and lesser black-backed gulls Larus fuscus also showed high aggregation at vessels, and lower index scores resulted for herring gulls Larus argentatus and northern gannets Morus bassanus. Most offal was consumed by northern fulmars, and a high proportion of discarded roundfish was taken by great black-backed gulls (Table 3 ). Smaller proportions were taken by gannets, great skuas and herring gulls (Table 3). Despite their numerical predominance at fishing vessels, northern fulmars swallowed rather few discards, and so had a discard consumption success index of only 0.2 , far lower than achieved by herring gulls (3.6), lesser black-backed gulls (5.3), great black-backed gulls (11.8), great skuas (28.9), or northern gannets (50.2). Fulmars primarily swallowed whiting $<20 \mathrm{~cm}$ length and hardly took any whiting $>25$ $\mathrm{cm}$, showing very strong selection for smaller fish than those typically being discarded by the trawl fishery in the north-western North Sea (Fig. 2). Comparison of the sizes of fish swallowed by seabirds of different sizes (Fig. 3) suggests that most of the variation in size preferences relate to differences in body size and so the ability of birds to swallow the fish easily. However, the species falling furthest below the regression line in Fig. 3 is the northern fulmar. This species seems to take relatively smaller discards than would be predicted from its body size.

North Sea fisheries show little seasonal variation in discarding rates, although amounts discarded vary among years according to recruitment strength of key fish species, such as whiting and haddock (ICES Work-

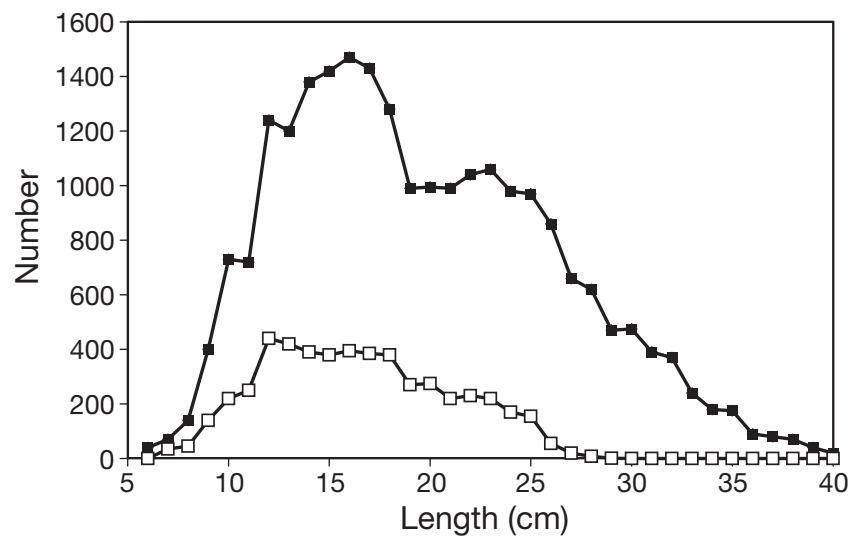

Fig. 2. Merlangius merlangus and Fulmarus glacialis. Numbers of whiting of different lengths ( $\square$ ) in samples of discards from trawlers in the North Sea from 1993 to 1994, and the numbers of these that were swallowed by northern fulmars $F$. glacialis (ㅁ) (derived from data in Camphuysen et al. 1995)

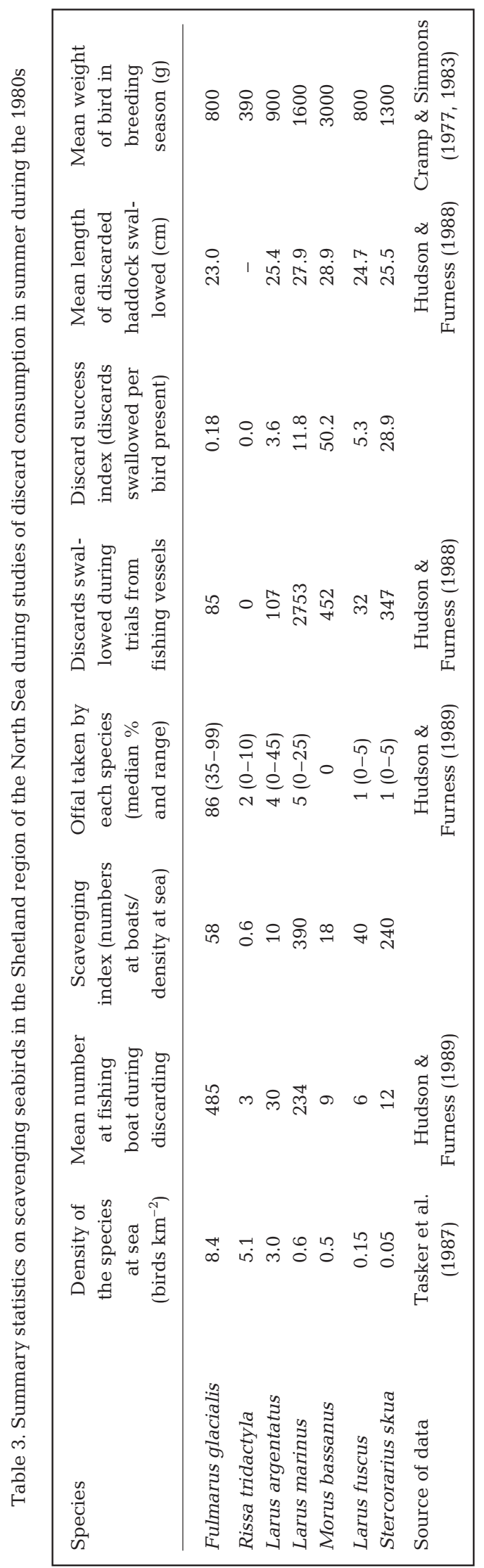




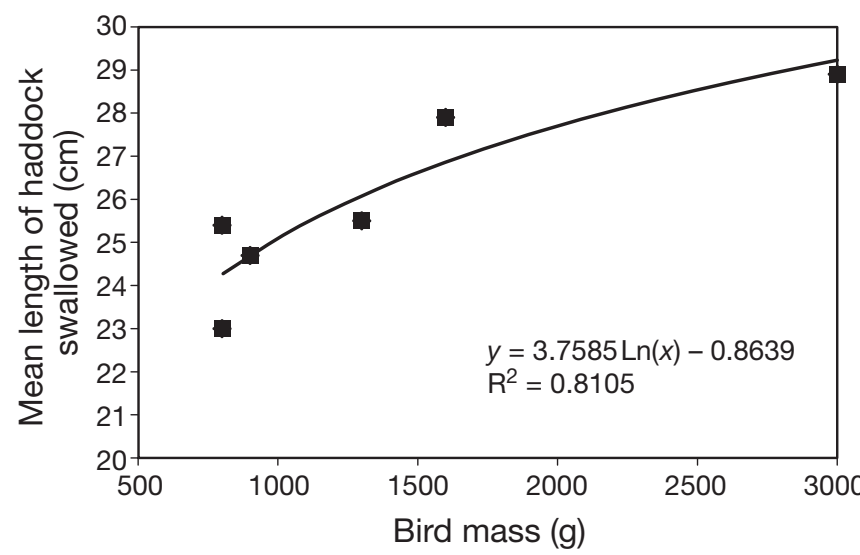

Fig. 3. Melanogrammus aeglefinus. Mean lengths of haddock swallowed by different scavenging seabird species at Shetland in relation to bird size (data on discards swallowed from Hudson \& Furness 1988; data on bird body masses from Cramp \& Simmons 1977, 1983)

ing Group reports at www.ices.dk). Higher consumption rates by seabirds in winter (Table 1) may reflect increased numbers of gulls in the North Sea as a result of migrations of populations breeding at higher latitudes, but also probably reflect the fact that sandeels Ammodytes spp., a major food of most seabirds in the North Sea in summer, are in the seabed and unavailable to most seabirds in winter, so that there seems to be more competition for discards in winter in this region.

\section{The western Mediterranean Sea}

Although purse-seine fisheries also discard amounts of small pelagics due to fluctuations in market prices or to partly damaged catch, most discards come from trawl fisheries, and these have been the focus of study. Discarding rates in Mediterranean trawl fisheries can be high: ca. $45 \%$ in the north-eastern region (Aegean and Ionian Seas), and slightly lower, due to higher net mesh size, in the western areas (Gulf of Lyon, CatalanBalearic Sea) (Machias et al. 2001, Mallol 2005). Furthermore, discarding rates are very variable, ranging from 8 to $73 \%$ depending on year, season, area and targeted fish (Oro \& Ruiz 1997, Arcos 2001, MartínezAbraín et al. 2002, Mallol 2005). The number of species discarded can also be very variable (Sanchez et al. 2004). Studies of discard consumption by seabirds in the western Mediterranean Sea have found seasonal and regional variations, with higher consumption outside of the breeding season and in areas where Audouin's gulls Larus audouinii are numerous; at the Ebro Delta 72 to $81 \%$ of discards were taken by seabirds; off Barcelona, $84 \%$; at Mallorca, $64 \%$; but at Benidorm, only 54\% (Oro \& Ruiz 1997, Arcos 2001,
Martínez-Abraín et al. 2002). The sizes of discards from the Mediterranean trawl fishery were much smaller than those in the North Sea fisheries, with an average length of only around $10 \mathrm{~cm}$ for roundfish and $8 \mathrm{~cm}$ for flatfish (Table 2). Scavenging is also favoured by the discard of sardine Sardina pilchardus, which forms a large proportion of the catches (in several regions it is the predominant species by biomass in the catches). Discarding of sardines occurs when there is a fall in market interest in this species (Mallol 2005). Sardines are the main natural prey for most seabirds in the Mediterranean, so their discarding is very suitable for scavenging species, with consumption rates of up to $100 \%$ (Oro \& Ruiz 1997, Martínez-Abraín et al. 2002).

Management of Spanish Mediterranean trawl fisheries involves periodical closures of the fishery (moratoria) to protect stocks from over-exploitation, contributing, in turn, to sustainable management. Around the Ebro Delta, which is one of the most important fishing grounds for trawling in the Mediterranean, a trawling moratorium has been imposed for 2 mo each year since 1991, and, during these periods, the availability of discards to scavengers abruptly falls to zero. The area covers ca. $250 \mathrm{~km}$ of coastline and holds 11 harbours. Commercial catches from 1990 to 2005 were, on average, $30.0 \times 10^{6} \mathrm{~kg} \mathrm{yr}^{-1}\left(\mathrm{SE}=5.0 \times 10^{5}\right)$; the main targeted species were European hake Merluccius merluccius and blue whiting Micromesistius poutassou. Several studies quantified fish discarded by trawl fisheries and discards consumed by scavenging seabirds (e.g. Arcos 2001). Similar studies were carried out at other areas (Oro \& Ruiz 1997, Arcos \& Oro 2002, Martínez-Abraín et al. 2002), and also used data from Mallorca (Balearic archipelago) for comparison: here oceanographic features are very different, with narrow continental shelves and lower productivity, resulting in much lower commercial catches $\left(1.4 \times 10^{6} \mathrm{~kg} \mathrm{yr}^{-1}\right)$, different targeted species (mainly mullets Mullus spp., European hake, and red shrimp Aristeus antennatus) and a smaller seabird community, with potential consequences on the amounts of discarded fish available for benthic scavengers.

A simple model was based on an equation estimating the discards $\left(\mathrm{kg} \mathrm{mo}^{-1}\right)$ consumed by seabirds from the total commercial catches (DC, \%)-while $(1-\mathrm{DC})$ is the percentage of discards sunk from the total commercial catches and available for benthic scavengersto have a rough estimate of this parameter in a given time and area. We obtained DC by multiplying a set of variables, for which good quality data exist (see Arcos 2001; Table 2 present paper):

$$
\mathrm{DC}=\mathrm{CC} \times \mathrm{DR} \times \mathrm{CR}
$$

where CC was commercial catches (landings of the trawling fisheries), DR was discard ratio (relative to 
landings) and CR was consumption rate (proportion of discards taken by seabirds). The model was applied during the breeding season of seabirds (from April to July) to the areas of the Ebro Delta and Mallorca Is. For each variable, we generated (by bootstrapping) a simulated data set, randomly drawn from the corresponding distribution. The resulting mean values were introduced in the previous equations to compute an averaged value of $\mathrm{DC}$, and the process was run 1000 times, thus obtaining a probability distribution of DC means (J. Arcos et al. unpubl. data). The ratio of discards consumed by seabirds relative to landings (DR) was estimated at 0.371 (95\% CI: 0.351/0.390) and 0.139 (95\% CI: 0.131/0.147) at the Ebro Delta and Mallorca, respectively. The variability in the parameter DC in the Mediterranean is very high due to the high biodiversity in fish communities and the variability in targeted species, as well as the heterogeneity in seabird colony distributions, with decreasing fleets and breeding numbers from western to eastern parts of the sea. Even at small spatial scales, such as the neighbouring areas of the Ebro Delta, Barcelona and Mallorca, the variation is high depending on the type of haul, sea depth and type of substrate (see Table 4). Despite this variability, the amounts of discards sinking and available for benthic scavengers should be high despite the fraction consumed at the surface or just beneath by scavenging seabirds.

\section{The eastern Bering Sea}

The Bering Sea is characterized by concentrations of planktivorous, piscivorous and omnivorous birds, whose distributions are determined by ocean depths, currents and topographic features that determine prey distributions (Piatt \& Springer 2003). Commercial fishing makes a considerable amount of food available to surface scavengers, possibly altering the distributions of some bird species. However, there is variation among fisheries in the BSAI fishery management region in the quantities, sources and seasonality of bio- mass returned to the sea and thus made available to seabirds and subsequently to benthic scavengers.

The midwater trawl fishery, which targets pollock Theragra chalcogramma is both one of the biggest and one of the most selective fisheries in the world, taking a catch of pollock valued at more than a billion US dollars per year. In the BSAI fishery management area in 2005 , of the $805652 \mathrm{t}$ of fish brought on board at-sea processing vessels by the midwater trawl fishery, only $0.6 \%$ of the total catch was discarded back to the sea (Table 5). Another $0.8 \%$ of the total catch consisted of whole fish that might have been discarded back to the sea, but instead were made into fishmeal while at sea (Table 5). Thus, the high volume midwater trawl fishery provides few discards to seabirds or the marine ecosystem as a whole. In contrast, offal (the parts of the fish remaining after the marketable parts have been extracted) is produced and returned to the marine environment in prodigious quantities (see below). The bottom trawl fishery in the BSAI is smaller and much less selective than the midwater trawl fishery. Of $>316000$ t of fish caught in the BSAI bottom trawl fishery, $22 \%$ were discarded back to the sea (Table 5). The longline fishery handles even smaller quantities of fish (ca. $145000 \mathrm{t}$ total catch), but is intermediate in its selectivity, returning $11 \%$ of the total catch to the sea. Because of differences in selectivity, the smaller bottom trawl fishery returns a greater biomass of discards to the ocean than does the large midwater trawl fishery ( $>69000 \mathrm{t}$ versus $<5000 \mathrm{t}$ ).

The fisheries also vary in the quantity of offal returned to the marine environment. In 2005, at-sea processors for the midwater trawl fishery returned about $419000 \mathrm{t}$ to the sea, while at-sea processors for the bottom trawl fishery and the longline fishery returned about 53000 and $56000 \mathrm{t}$, respectively. These differences arise because the fisheries differ in the mean proportion of each fish that becomes offal, ranging from $53 \%$ in the midwater trawl fishery, which usually removes heads, guts, skin and bone, to $24 \%$ in the bottom trawl fishery, which may only head and gut fish, or simply sell them whole or merely bled (Table 5),

Table 4. Landed catches, discards and offal per haul (in kg), according to the type of haul and the area in the north-western Mediterranean. The ratio of discards versus landed captures is also provided (DR), as well as the percentage of discards a priori consumable by seabirds (consumable fraction, CF). Hauls: number of hauls. Data from Arcos (2001)

\begin{tabular}{|c|c|c|c|c|c|c|c|c|c|c|c|c|}
\hline & \multicolumn{6}{|c|}{ Continental shelf } & \multirow{2}{*}{\multicolumn{3}{|c|}{ Upper slope }} & \multicolumn{3}{|c|}{ Mid-slope } \\
\hline & \multicolumn{3}{|c|}{ Barcelona } & \multicolumn{3}{|c|}{ Ebro Delta } & & & & & & \\
\hline & Hauls & Mean & Range & Hauls & Mean & Range & Hauls & Mean & Range & Hauls & Mean & Range \\
\hline Catches (kg) & ) 23 & 124.2 & $13-550$ & 36 & 184.4 & $57-850$ & 21 & 158.5 & $34-460$ & 28 & 59.7 & $5-230$ \\
\hline Discards $(\mathrm{kg})$ & g) 31 & 174.8 & $20-1125$ & 36 & 89.3 & $16-425$ & 31 & 120.8 & $14-690$ & 36 & 28.2 & $4-90$ \\
\hline Offal (kg) & 30 & 0.27 & $0-2$ & 36 & 0.17 & $0-2$ & 29 & 0.76 & $0-5$ & 34 & 0.29 & $0-3$ \\
\hline DR & 23 & 176.8 & $47.2-730$ & 36 & 56.1 & $8.2-212.5$ & 21 & 125.6 & $11.7-664$ & 28 & 46.3 & $14.5-110.3$ \\
\hline $\mathrm{CF}$ & 1 & 75.3 & - & 24 & 64.0 & $12.7-99.9$ & 1 & 96.8 & - & 1 & 88.5 & - \\
\hline
\end{tabular}


Table 5. Total catch and 'processed catch' (processed catch includes fish from which offal is generated when marketable products are produced, and fish sold whole, but excludes fish made into fishmeal) for 3 gear types in the Bering Sea/ Aleutian Islands groundfish fishery in 2005 for at-sea catcher/processors and at-sea processors (motherships) combined. Also discards, offal, fishmeal and other secondary products as percentages of total or processed catch. All values were calculated in tonnes of wet weight of fish or fish parts prior to any water loss due to processing

\begin{tabular}{|lccc|}
\hline & $\begin{array}{c}\text { Midwater } \\
\text { trawl }\end{array}$ & $\begin{array}{c}\text { Bottom } \\
\text { trawl }\end{array}$ & $\begin{array}{c}\text { Long- } \\
\text { line }\end{array}$ \\
\hline Total catch (t) & 805652 & 316762 & 145712 \\
Discards (\% of total catch) & 0.6 & 22 & 11 \\
$\begin{array}{l}\text { Whole fish made into } \\
\text { fishmeal (\% of total catch }\end{array}$ & 0.8 & 0.5 & 0.0 \\
$\begin{array}{l}\text { Processed catch (t) } \\
\text { Offal discarded at sea }\end{array}$ & 794329 & 230004 & 113172 \\
$\begin{array}{l}\% \text { of processed catch) } \\
\text { Offal made into fishmeal } \\
\text { and oil (\% of processed catch) }\end{array}$ & 14 & 24 & 50 \\
$\begin{array}{l}\text { Additional secondary } \\
\text { products (e.g. roe or meat } \\
\text { from cheeks, bellies, etc.) }\end{array}$ & 3 & 2 & 0 \\
(\% of processed catch) & & & \\
\hline
\end{tabular}

as well as in the overall quantity of fish processed. The presence of fishmeal and fish oil plants on board the larger processor vessels and the extraction of other secondary products, such as roe or meat from the cheeks, bellies, etc., reduces even further the amount of biomass returned to the sea (Table 5).

At-sea processors in the Bering Sea and Aleutian Islands are required by statute (Environmental Protection Agency regulations) to macerate all offal and virtually all discards discharged to the sea to chunks of approximately $1 \mathrm{~cm}$ in diameter. This has a considerable effect on the physical characteristics and, potentially, the fine-scale distribution of food presented to scavengers. These changes may potentially alter both the relative costs and benefits of boat-following for individual scavengers, as well as the competitive interactions within and between bird species, specifically increasing the benefit to smaller seabirds, such as fulmars, kittiwakes and shearwaters. No data currently exist quantifying the feeding patterns of seabirds behind fishing vessels in the Bering Sea. Counts, however, do exist for 2002 to 2004 for the 3 mo of summer. Northern fulmars are the most commonly observed species behind longline vessels in the Bering Sea (93\% of all birds observed behind research longline vessels in the Bering Sea) and the Aleutian Islands (64\%), followed by albatrosses (2 and 17\%), gulls (1 and 18\%), kittiwakes and shearwaters ( $\leq 3 \%$; Melvin et al. 2006). Although northern fulmars are numerically dominant, preliminary data suggest that albatrosses (predomi-

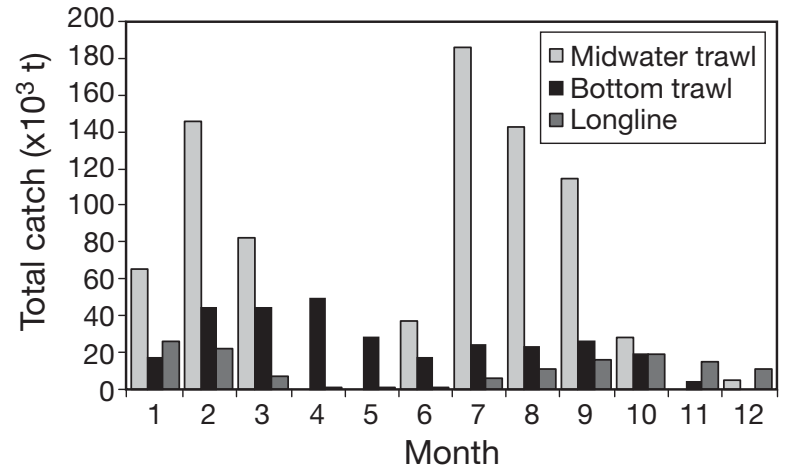

Fig. 4. Total catch in 2005 by month (1: Jan; 2: Feb; etc.) for at-sea processors of groundfish in the Bering Sea/Aleutian Islands fishery management region, for 3 gear types, showing the strongly seasonal nature of the midwater trawl fishery and the longline fishery

nantly Laysan albatrosses Phoebastria immutabilis and black-footed albatrosses $P$. nigripes, but also small numbers of short-tailed albatrosses $P$. albatrus) occur behind fishing vessels in disproportionately high numbers, i.e. they appear to have a high seabird scavenging index relative to other species in the BSAI (A. Edwards unpubl. data), despite the fact that they will have to work harder to obtain the equivalent of a whole fish when feeding on macerated discards.

Both fishing activity and seabird presence vary seasonally in the BSAI. All fisheries are bimodal to some degree, with peaks of activity from approximately January through March and July through October (Fig. 4). Albatrosses and shearwaters are seasonal migrants whose numbers increase during the non-breeding, summer months. Fulmars, kittiwakes and gulls breed in the Alaskan region during the summer and generally remain within the region during the winter. The quantity of discards, and especially offal, released to the marine environment in the Bering Sea (Table 5) exceeds the energetic requirements of the surfacescavenging, boat-following seabirds (predominantly fulmars) present in the Bering Sea during the summer (Hunt et al. 2000), suggesting that, in the Bering Sea, seabirds may have only a limited impact on the quantity of fisheries discards and offal that reach benthic scavengers.

\section{DISCUSSION}

\section{Discarding practices}

Our review found enormous differences in the amounts and types of waste produced by different fisheries. The midwater trawl fishery in the eastern Bering Sea discards rather few fish, and this mostly in a macerated form, whereas it discards large quantities of 
offal (Table 5), also predominantly in a macerated form, and waste is predominantly produced in early spring and late summer/early autumn (Fig. 4). The trawl fishery in the western Mediterranean generates large quantities of discards comprising whole small fish, but little offal from fish gutted at sea (Table 4), but with short periods when the fishery is closed and no discarding occurs. In the North Sea trawl fisheries there is little seasonal variation, but large quantities of offal and large whole fish are discarded (Garthe et al. 1996; Table 2 present paper). Maceration of offal and discards by catcher-processors in the eastern Bering Sea make material more suitable for consumption by smaller scavenging seabirds and perhaps less attractive for larger scavenging seabirds, whereas, in the North Sea, the large size of most discards makes these unsuitable for smaller scavenging seabirds. Fishery closures and seasonal fisheries may result in scavenging seabirds being unable to rely on fishery waste as a consistent food supply, and this may lead to lower exploitation of this food resource by seabirds.

\section{Selection by seabirds}

Consumption rates were not significantly different for roundfish and flatfish discards in the Mediterranean studies, in contrast to the pattern seen in the North Sea, where seabirds tended to avoid flatfish. In the western Mediterranean, some discarded fish species were positively selected (e.g. sardine, bogue Boops boops, gadiforms), whereas others were avoided (e.g. chondrychthies, gobids and dragonets) (Oro \& Ruiz 1997, Arcos 2001). Most scavenging seabird species in the Mediterranean are surface feeders (terns and gulls) and exploit species remaining near or at the surface for some time (e.g. bogues and some gadiforms), while shearwaters can dive and probably catch fish that sink more quickly (e.g. anchovy Engraulis encrasicholus). The species most strongly avoided by seabirds in the Mediterranean tend to be roundfish with large spines that are obviously difficult for birds to swallow. In the North Sea, most roundfish discards are not spiny, and seabirds appear to avoid flatfish. The flatfish discarded by the North Sea fisheries tend to be rather large (typically $23 \mathrm{~cm}$ in the whitefish trawl fishery) and so will be difficult for seabirds to swallow. In contrast, flatfish discarded in the western Mediterranean tend to be much smaller (typically $8 \mathrm{~cm}$ ), and this seems to be small enough that seabirds can more easily swallow these than spiny roundfish. This difference results in the contrasting pattern of discard selection demonstrated in Fig. 1. Essentially, seabirds select discards that are relatively easy to swallow, which is strongly influenced by seabird size and by fish mor- phology, as well as size. In all regions seabirds are likely to show less interest in discarded benthic invertebrates, while offal tends to be consumed quickly.

\section{Implications for scavenging seabirds}

In the North Sea, breeding numbers of scavenging seabirds have increased several fold during the 20th century, possibly due to improved body condition and breeding performance, resulting from the availability of this extra food (Mitchell et al. 2004). However, in recent years there have been large reductions in the amounts of demersal fish made available to scavenging seabirds in the northern North Sea, partly as a result of reduced fishing effort on gadoids and partly due to changes in technical measures, such as net mesh size and design (Votier et al. 2004, Hall \& Mainprize 2005). In the western Mediterranean, there are also indications that discards support elevated breeding numbers of scavenging seabirds, although fishery moratoria may cause breeding failures and preyswitching interactions among seabird species (Arcos \& Oro 2002, Oro et al. 2004). There is little information on the extent to which fishery waste in the eastern Bering Sea affects seabird numbers or distribution, although it is known that large numbers of northern fulmars and other seabirds scavenge on fishery waste. The practice of macerating waste to small bite-sized pieces $(\sim 1 \mathrm{~cm})$ before discharge could have a considerable effect on its use by seabirds. Thus, it would be interesting to investigate consumption rates of offal and discards in the eastern Bering Sea. Evidence from studies in the North Sea suggests that maceration increases the suitability of waste for consumption by northern fulmars. It may be necessary to reduce waste to an essentially liquid form to make it unsuitable as food for seabirds.

\section{Implications for benthic scavengers}

In a wide variety of marine ecosystems around the world, scavenging seabirds consume a high proportion of discards from fishing vessels, and show strong selection for more easily swallowed items and probably for fish of higher calorific content. Some sinking discards that are not consumed by seabirds are probably eaten by pelagic fish, although there are few data on this. Some studies in the eastern Bering Sea suggest that Pacific cod may scavenge on sinking fishery waste, based on analysis of Pacific cod stomach contents that could be identified as macerated discards (Alaska Fisheries Science Center unpubl. data). The fisheriesderived biomass that reaches the benthic scavenging community will vary in quantity and species composi- 
tion relative to that discarded at the ocean's surface. The effect of seabird scavengers on marine ecosystems can vary seasonally, for example, in the North Sea seabirds take more discards in winter. Given the high rates of consumption by seabirds of offal and discarded fish, in at least some parts of the world, it would be inappropriate to infer that discarding always provides a means of recycling material back into marine fish via the benthos. Part of the nutrients taken up by seabirds from discards and offal will be excreted on land if these birds are roosting ashore or attending colonies, while the nutrients excreted at sea are likely to enter the pelagic ecosystem rather than the benthic.

\section{Implications for future fisheries management}

Our 3 examples, the North Sea, the western Mediterranean Sea and the eastern Bering Sea, provide highly divergent pictures of fisheries management practices, but common principles of discard use by scavenging seabirds. As a broad generalisation, scavenging seabirds take a high proportion of fisheries offal and discards, but avoid items of low nutritional quality (low energy content or low digestibility), such as benthic invertebrates, and avoid fish that are difficult to swallow, either due to large size, to shape, or to presence of spines and other defence structures. It is clear that management practices such as macerating discards greatly influence the suitability of this waste as food for seabirds and will alter the competitive balance between larger and smaller species. Seasonal closures of fisheries have a great impact on scavenging seabirds, by creating bottlenecks that may limit the numbers or breeding success of scavenging seabirds when they are forced to switch to more natural feeding. The highly selective consumption of fisheries discards and offal by seabirds will have a filtering effect moderating the amounts and types of waste reaching the benthic scavenging community. The current trend to reduce discarding is already having impacts on scavenging seabirds (Oro et al. 2004, Votier et al. 2004). However, we recommend that strong efforts should be made to reduce discarding as much as possible. We should not recommend a continuation of current discarding practices for the sake of scavenging seabirds, as these artificially sustain elevated populations of scavengers, and it would be preferable to see these populations brought back to pre-discarding sustainable levels. In particular, we should be aware of the problem of longline bycatch of scavenging seabirds, which could probably be reduced if fishing vessels did not provide any offal or discards to attract these birds to feed at vessels. A policy of no discarding at sea, or of liquidisation of discards and offal before discharge, so that these no longer provide food for seabirds may be a significant mitigation measure to reduce the problem of longline bycatch of seabirds (Melvin et al. 2006) and the disruption to seabird communities caused by sudden changes in discarding practice (Votier et al. 2004).

Acknowledgements. This study was carried out while R.W.F. held a Leverhulme Trust Research Fellowship and A.E.E. was sponsored by a National Research Council Postdoctoral Fellowship with the Alaska Fisheries Science Center-NOAA. The Natural Environment Research Council funded early work on scavenging seabirds at Shetland, and recent work both in the North Sea and western Mediterranean was supported by the EC Contract 'DISCBIRD'.

\section{LITERATURE CITED}

Alverson DL, Freeberg MH, Murawski SA, Pope JG (1994) A global assessment of fisheries bycatch and discards. FAO Fish Tech Pap 339:1-233

Arcos JM (2001) Foraging ecology of seabirds at sea: significance of commercial fisheries in the NW Mediterranean. $\mathrm{PhD}$ thesis, University of Barcelona

Arcos JM, Oro D (2002) Significance of fisheries discards for a threatened Mediterranean seabird, the Balearic shearwater Puffinus mauretanicus. Mar Ecol Prog Ser 239:209-220

Bertellotti M, Yorio P (2000) Utilisation of fishery waste by kelp gulls attending coastal trawl and longline vessels in northern Patagonia, Argentina. Ornis Fenn 77:105-115

Broadhurst MK, Suuronen P, Hulme A (2006) Estimating collateral mortality from towed fishing gear. Fish Fish 7: 180-218

Brooke M de L (2004) The food consumption of the world's seabirds. Proc R Soc Lond B (Suppl) 271:246-248

Camphuysen CJ, Calvo B, Durinck J, Ensor K and others (1995) Consumption of discards by seabirds in the North Sea. NIOZ Rapport 1995-5, Netherlands Institute for Sea Research, Den Burg

Catchpole TL, Frid CLJ, Gray TS (2006) Importance of discards from the English Nephrops norvegicus fishery in the North Sea to marine scavengers. Mar Ecol Prog Ser 313: $215-226$

Cramp S, Simmons KEL (1977) The birds of the western Palearctic, Vol 1. Oxford University Press, Oxford

Cramp S, Simmons KEL (1983) The birds of the western Palearctic, Vol 3. Oxford University Press, Oxford

Del Hoyo J, Elliot A, Sargatal J (eds) (1992) Handbook of the birds of the World, Vol 1. Lynx Edicions, Barcelona

Del Hoyo J, Elliot A, Sargatal J (eds) (1996) Handbook of the birds of the World, Vol 3. Lynx Edicions, Barcelona

Garthe S, Scherp B (2003) Utilization of discards and offal from commercial fisheries by seabirds in the Baltic Sea. ICES J Mar Sci 60:980-989

Garthe S, Camphuysen CJ, Furness RW (1996) Amounts of discards by commercial fisheries and their significance as food for seabirds in the North Sea. Mar Ecol Prog Ser 136:1-11

González-Zevallos D, Yorio P (2006) Seabird use of discards and incidental captures at the Argentine hake trawl fishery in the Golfo San Jorge, Argentina. Mar Ecol Prog Ser 316:175-183

Hall SJ, Mainprize BM (2005) Managing by-catch and discards: How much progress are we making and how can we do better? Fish Fish 6:134-155 
Hudson AV, Furness RW (1988) Utilization of discarded fish by scavenging seabirds behind whitefish trawlers in Shetland. J Zool Lond 215:151-166

Hudson AV, Furness RW (1989) Behaviour of seabirds foraging at fishing boats around Shetland. Ibis 131:225-237

Hunt GL, Kato H, McKinnell SM (2000) Predation by marine birds and mammals in the subarctic North Pacific Ocean. PICES Sci Rep 14, North Pacific Marine Science Organization, Seattle, WA

Karpouzi VS, Watson R, Pauly D (2007) Modelling and mapping resource overlap between seabirds and fisheries on a global scale: a preliminary assessment. Mar Ecol Prog Ser 343:87-99

Louzao M, Igual JM, McMinn M, Aguilar JS, Triay R, Oro D (2006) Small pelagic fish, trawling discards and breeding performance of the critically endangered Balearic shearwater: improving conservation diagnosis. Mar Ecol Prog Ser 318:247-254

Machias A, Vassilopoulou V, Vatsos D, Bekas P, Kallianiotis A, Papaconstantinou C, Tsimenides N (2001) Bottom trawl discards in the northeastern Mediterranean Sea. Fish Res 53:181-195

Mallol S (2005) Análisi dels descartaments efectuats per la flota d'arrossegament en el Golf de Lleó. PhD thesis, University of Girona

Martínez-Abraín A, Maestre R, Oro D (2002) Demersal trawling waste as a food source for western Mediterranean seabirds during the summer. ICES J Mar Sci 59:529-537

Melvin EF, Wainstein MD, Dietrich KS, Ames KL, Geernaert TO, Conquest LL (2006) The distribution of seabirds on the Alaskan longline fishing grounds: implications for seabird avoidance regulations. Project A/FP-7, Washington Sea Grant Program, Seattle, WA

Editorial responsibility: Howard Browman (Associate Editorin-Chief), Storebø, Norway
Mitchell PI, Newton SF, Ratcliffe N, Dunn TE (eds) (2004) Seabird populations of Britain and Ireland. T. \& A. D. Poyser, London

Oro D, Ruiz X (1997) Seabirds and trawler fisheries in the northwestern Mediterranean: differences between the Ebro Delta and the Balearic Is. areas. ICES J Mar Sci 54:695-707

Oro D, Cam E, Pradel R, Martínez-Abraín A (2004) Influence of food availability on demography and local population dynamics in a long-lived seabird. Proc R Soc Lond B 271:387-396

Piatt JF, Springer AM (2003) Advection, pelagic food webs and the biogeography of seabirds in Beringia. Mar Ornithol 31:141-154

Sanchez P, Demestre M, Martin P (2004) Characterisation of the discards generated by bottom trawling in the northwestern Mediterranean. Fish Res 67:71-80

Sullivan BJ, Reid TA, Bugoni L (2006) Seabird mortality on factory trawlers in the Falkland Islands and beyond. Biol Conserv 131:495-504

Svane I (2005) Occurrence of dolphins and seabirds and their consumption of by-catch during prawn trawling in Spencer Gulf, South Australia. Fish Res 76:317-327

Tasker ML, Webb A, Hall AJ, Pienkowski MW, Langslow DR (1987) Seabirds in the North Sea. Nature Conservancy Council, Peterborough

Thompson KR, Riddy MD (1995) Utilization of offal and discards from 'fin-fish' trawlers around the Falkland Islands by the black-browed albatross Diomedea melanophris. Ibis 137:198-206

Votier SC, Furness RW, Bearhop S, Crane JE and others (2004) Changes in fisheries discard rates and seabird communities. Nature 427:727-730

Submitted: December 13, 2006; Accepted: March 1, 2007 Proofs received from author(s): October 29, 2007 